\title{
Effects of Timing of Copper Sprays, Defoliation, Rainfall, and Inoculum Concentration on Incidence of Olive Knot Disease
}

\author{
Beth L. Teviotdale, Department of Plant Pathology, University of California-Davis, Kearney Agricultural Center, \\ Parlier 93648; and William H. Krueger, University of California-UCCE, Orland 95963
}

\begin{abstract}
Teviotdale, B. L., and Krueger, W. H. 2004. Effects of timing of copper sprays, defoliation, rainfall, and inoculum concentration on incidence of olive knot disease. Plant Dis. 88:131-135.

The olive knot pathogen, Pseudomonas savastanoi, causes galls on shoots, branches, fruit, and leaves. Shoots girdled by galls die. Any fresh wound is susceptible to infection, but the most common entry sites are leaf scars. Leaf scars are most susceptible to infection during the first 2 days after leaf fall and remain susceptible for 7 more days. Simulated leaf scars on 'Manzanillo' olive trees were created by removing leaves from healthy shoots at approximately monthly intervals from December through June 1997-98, 1998-99, and 1999-2000. Trees were treated with a water suspension of cupric hydroxide (Kocide DF40) at $3 \mathrm{~g} /$ liter one, two, or three times in 1998-99 and 1999-2000 with a hand-gun sprayer. Generally, disease control improved with more applications $(P=0.008$ and 0.032 in 1999 and 2000, respectively). Disease incidence was greatest on shoots that were defoliated in March 1998, April and June 1999, and March and May 2000. Cumulative rainfall 2 and 9 days after each defoliation was recorded. Disease incidence was positively correlated $(P=0.031$ and 0.023 for 2 and 9 days, respectively) with spring (March through June) but not winter (December through February) rainfall. Comparable simulated leaf scars were inoculated in December and April 1997-98 and 1998-99 with $10^{4}, 10^{6}$, and $10^{8} \mathrm{CFU} / \mathrm{ml}$ of the pathogen and treated with a water suspension of cupric hydroxide at 3 $\mathrm{g} /$ liter using a handheld pump sprayer. Inoculated and noninoculated, nontreated shoots were included. More disease developed in April than in December inoculations $(P=<0.0001)$ in both years. Disease incidence increased with increasing inoculum concentration $(P=<0.0001)$ in both years and was lower in shoots treated with Kocide DF40 $(P=<0.0001)$. Our work demonstrated that the common grower practice of one post-harvest application of copper bactericide provides only minimal protection against olive knot, and that additional sprays in spring are needed to substantially improve disease control.
\end{abstract}

Olive knot disease is widespread throughout the major olive (Olea europaea L.)-growing regions of California. It is generally more prevalent and severe in the northern areas of the state where rainfall is greater. Of the cultivars commercially grown in California, 'Manzanillo' is the most susceptible. Increased plantings of 'Manzanillo' trees coupled with lateseason rains have made the disease more noticeable in recent years.

The disease is caused by the bacterium Pseudomonas savastanoi (ex. Smith) Gardan, Bollet, Abu Ghorrah, Grimont \& Grimont 1992 (8). The bacteria are spread by wind and rain and may infect any wound, including leaf, blossom, raceme, and peduncle scars, tiny cracks in the bark where shoots emerge, pruning wounds, and frost or hail injuries (8). Galls form only when the tree is growing; thus, winter infections develop into galls when growth

Corresponding author: B. L. Teviotdale

E-mail: betht@uckac.edu

Accepted for publication 31 August 2003.

Publication no. D-2003-1124-01R

(C) 2004 The American Phytopathological Society resumes in spring (8). The bacteria survive in galls and exude to the surface during wet periods. In Italy, the pathogen is also a frequent inhabitant of the phylloplane (1). Systemic invasion of the olive tree is infrequent and limited (9).

Leaf scars are the most common sites of infection, and small galls often are found at the nodes along shoots (8). Shoots girdled by infection usually die, reducing the fruit production potential of the tree (7). Leaf scars are most susceptible to infection during the first 2 days after the leaf falls, and remain vulnerable for another 7 days (3). Olive trees are evergreen, and healthy leaves remain attached to shoots for 2 or 3 years. Trees drop some leaves all year, but most leaves drop over several weeks during mid- to late spring. Thus, trees are at greatest risk of infection during spring leaf fall. Frost injury or other defoliating diseases, principally olive leaf spot caused by the fungus Spilocaea oleaginea (Castagne) S. J. Hughes, exacerbate spring leaf fall, thereby increasing the number of potential sites of infection by the olive knot pathogen (6). Excessive leaf fall coupled with rain may result in more severe olive knot disease.

Early work on the control of olive knot established that good protection usually required treatment in fall, winter, and early spring (8). However, treatment before harvest, which may be as late as November, leaves unacceptable copper residues on the fruit, and growers often are reluctant to treat again in spring for economic reasons. Thus, the common practice among California growers has been to apply one treatment of copper-containing bactericide after harvest. This practice protects against olive leaf spot but provides only minimal protection against olive knot. Our objectives were to demonstrate the importance of spring treatments for disease control; to compare the effectiveness of one, two, and three applications of copper bactericide; to relate disease incidence to rain; and to test the effect of inoculum concentration on disease incidence.

\section{MATERIALS AND METHODS}

The experiments were conducted in a commercial olive orchard planted with cv. 'Manzanillo' olive trees and located in Tehama County, CA. Trees were 6 years old at the beginning of the experiment, spaced 4 by $8 \mathrm{~m}$, and irrigated by microsprinklers. The experiments were located on different trees each year. Olive knot infections were prevalent throughout the orchard.

Copper application timing. Trees were treated one, two, or three times in 1998-99 and 1999-2000, according to the treatment schedules shown in Tables 1 and 2, respectively. Each tree was sprayed to runoff with approximately 11.3 liters of a suspension of $3 \mathrm{~g}$ of cupric hydroxide (Kocide DF 40; Griffin Corp. Valdosta, GA) per liter of water. The material was applied with a hand-gun sprayer operated at $1.4 \times 10^{6} \mathrm{~Pa}$. There were five single-tree replications of 10 treatments arranged in a randomized complete block design.

We tracked the relative protection that these treatments provided for small wounds made at different times during the season. Locating and monitoring sufficient numbers of natural leaf scars of the same age throughout the winter and spring was impossible; therefore, we created simulated leaf scars by removing 10 pairs of mature leaves from 10 adjacent nodes on healthy 1- or 2-year-old shoots (20 wounds per shoot). In all treatments, five shoots per tree were defoliated on each application date immediately before copper was applied. Thus, on each tree, some wounds were made on the day of treatment and others were made weeks or months before or after treatment. The numbers of 
wounds at which galls developed on the defoliated shoots were counted on $18 \mathrm{Au}$ gust 1999 and 24 July 2000. The percentage of infected wounds for each defoliation date on each tree was calculated. The percentage of infected wounds combined from all defoliation dates ( 25 shoots) on each tree represented the disease incidence on each tree for the season.

Rainfall and disease incidence. Rainfall data were collected by the California Irrigation Management Information System at Station \#8 in Gerber, CA, approximately $13 \mathrm{~km}$ from the site of the experiments. Cumulative amounts of rainfall during the first 2 days (the most susceptible period for leaf scars) and 9 days (the maximum susceptible period for leaf scars) after each defoliation event were associated with disease incidence in 1998, 1999, and 2000. Data from the nontreated control trees, including addi- tional nontreated trees that were defoliated on 21 January and 24 June 1999 and 3 January and 5 June 2000 in the copper application timing experiments, were used

Table 3. Analysis of variance for experiments on the effects of copper application timing and defoliation date on natural incidence of olive knot disease, caused by Pseudomonas savastanoi, on defoliated shoots of 'Manzanillo' olive trees, Tehama County, $\mathrm{CA}^{\mathrm{z}}$

\begin{tabular}{|c|c|c|c|c|c|}
\hline \multirow[b]{2}{*}{ Sources of variation } & \multirow[b]{2}{*}{ df } & \multicolumn{2}{|c|}{1999} & \multicolumn{2}{|c|}{2000} \\
\hline & & MS & $F$ value & MS & $F$ value \\
\hline Replication & 4 & 451.3 & $4.561 * *$ & 17.4 & 0.235 \\
\hline Application timing & 9 & 866.5 & $8.756 * * *$ & $1,333.5$ & $18.030 * * *$ \\
\hline Error & 36 & 98.9 & $\ldots$ & 74.0 & $\ldots$ \\
\hline Defoliation date & 4 & $3,846.8$ & $76.754 * * *$ & $2,079.9$ & $51.723 * * *$ \\
\hline Application $\times$ defoliation & 36 & 238.8 & $4.765 * * *$ & 285.7 & $7.105 * * *$ \\
\hline Error & 160 & 50.1 & $\ldots$ & 63.2 & $\ldots$ \\
\hline
\end{tabular}

z Analysis of variance performed on arcsine transformed data. Values followed by $* *$ and $* * *$ are significantly different at $P<0.001$ and 0.0001 , respectively.

Table 1. Effects of copper application timing and defoliation date on natural incidence of olive knot disease, caused by Pseudomonas savastanoi, on defoliated shoots of 'Manzanillo' olive trees, Tehama County, CA, 1999w

\begin{tabular}{|c|c|c|c|c|c|c|c|c|c|c|}
\hline \multicolumn{5}{|c|}{ Number and dates of applications ${ }^{x}$} & \multicolumn{6}{|c|}{ Infected wounds (\%) by defoliation date ${ }^{y}$} \\
\hline 16 Dec & 22 Feb & 2 Apr & 3 May & 1 Jun & 16 Dec & 22 Feb & 2 Apr & 3 May & 1 Jun & Means $^{z}$ \\
\hline \multicolumn{11}{|l|}{ One application } \\
\hline $\mathrm{X}$ & $\ldots$ & $\ldots$ & $\ldots$ & $\ldots$ & $4.8 \mathrm{bc}$ & $6.0 \mathrm{~cd}$ & $26.4 \mathrm{abcd}$ & $7.4 \mathrm{a}$ & $47.0 \mathrm{ab}$ & $18.3 \mathrm{bc}$ \\
\hline$\ldots$ & $X$ & $\ldots$ & $\ldots$ & $\ldots$ & $6.6 \mathrm{abc}$ & $11.6 \mathrm{bcd}$ & $28.6 \mathrm{abc}$ & $7.8 \mathrm{a}$ & $45.8 \mathrm{ab}$ & $20.0 \mathrm{abc}$ \\
\hline$\ldots$ & $\ldots$ & $\mathrm{X}$ & $\ldots$ & $\ldots$ & $3.4 \mathrm{c}$ & $20.4 \mathrm{ab}$ & $10.8 \mathrm{de}$ & $5.2 \mathrm{a}$ & $41.4 \mathrm{ab}$ & $16.2 \mathrm{~cd}$ \\
\hline$\ldots$ & $\ldots$ & $\ldots$ & $\mathrm{X}$ & $\ldots$ & $15.0 \mathrm{a}$ & $28.6 \mathrm{a}$ & $32.4 \mathrm{ab}$ & $6.0 \mathrm{a}$ & $48.2 \mathrm{a}$ & $26.0 \mathrm{a}$ \\
\hline \multicolumn{11}{|l|}{ Two applications } \\
\hline $\mathrm{X}$ & $X$ & $\ldots$ & $\ldots$ & $\ldots$ & $4.8 \mathrm{bc}$ & $1.2 \mathrm{e}$ & $16.6 \mathrm{bcd}$ & $1.6 \mathrm{a}$ & $37.0 \mathrm{ab}$ & $12.2 \mathrm{de}$ \\
\hline$X$ & $\ldots$ & $\mathrm{X}$ & $\ldots$ & $\ldots$ & $5.4 \mathrm{bc}$ & $6.2 \mathrm{de}$ & $9.6 \mathrm{de}$ & $2.0 \mathrm{a}$ & $27.0 \mathrm{ab}$ & $10.0 \mathrm{de}$ \\
\hline $\mathrm{X}$ & $\ldots$ & $\ldots$ & $X$ & $\ldots$ & $4.0 \mathrm{bc}$ & $12.4 \mathrm{bcd}$ & $17.8 \mathrm{bcd}$ & $1.4 \mathrm{a}$ & $24.8 \mathrm{~b}$ & $12.0 \mathrm{de}$ \\
\hline \multicolumn{11}{|l|}{ Three applications } \\
\hline $\mathrm{X}$ & $X$ & $\ldots$ & $\mathrm{X}$ & $\ldots$ & $2.0 \mathrm{c}$ & $1.0 \mathrm{e}$ & $3.4 \mathrm{e}$ & $3.4 \mathrm{a}$ & $5.4 \mathrm{c}$ & $3.0 \mathrm{e}$ \\
\hline $\mathrm{X}$ & $\ldots$ & $\mathrm{X}$ & $\ldots$ & $\mathrm{X}$ & $2.2 \mathrm{c}$ & $8.0 \mathrm{~cd}$ & $13.2 \mathrm{cde}$ & $4.0 \mathrm{a}$ & $7.8 \mathrm{c}$ & $7.0 \mathrm{de}$ \\
\hline Nontreated control & $\ldots$ & $\ldots$ & $\ldots$ & $\ldots$ & $11.0 \mathrm{ab}$ & $15.8 \mathrm{bc}$ & $42.4 \mathrm{a}$ & $9.2 \mathrm{a}$ & $41.6 \mathrm{a}$ & $24.0 \mathrm{ab}$ \\
\hline Means, defoliation date & $\ldots$ & $\ldots$ & $\ldots$ & $\ldots$ & $5.9 \mathrm{~d}$ & $11.1 \mathrm{c}$ & $20.1 \mathrm{~b}$ & $4.8 \mathrm{~d}$ & $32.6 \mathrm{a}$ & $\ldots$ \\
\hline
\end{tabular}

${ }^{w}$ Incidence of disease, December 1998 (Dec) and February (Feb), April (Apr), May, and June (Jun) 1999. Analysis of variance was performed on arcsine transformed data; nontransformed data are presented. Means down columns (for application) and across the bottom row (means for defoliation date) followed by the same letter do not differ significantly according to Duncan's multiple range test.

${ }^{x}$ Cupric hydroxide (Kocide DF40), 3 g/liter of water, was applied to run-off using a hand-gun sprayer.

y Ten adjacent pairs of leaves were removed from each of five healthy 1- or 2-year-old shoots per tree on all trees in the experiment immediately before treatment on each application date. The number of infected wounds on each shoot was counted on 18 August 1999.

${ }^{\mathrm{z}}$ Means for application (season-long total).

Table 2. Effects of copper application timing and defoliation date on natural incidence of olive knot disease, caused by Pseudomonas savastanoi, on defoliated shoots of 'Manzanillo' olive trees, Tehama County, CA, 2000'

\begin{tabular}{|c|c|c|c|c|c|c|c|c|c|c|}
\hline \multicolumn{5}{|c|}{ Number and dates of applications ${ }^{x}$} & \multicolumn{6}{|c|}{ Infected wounds (\%) by defoliation date ${ }^{y}$} \\
\hline 2 Dec & 7 Feb & 3 Mar & 3 Apr & 5 May & 2 Dec & 7 Feb & 3 Mar & 3 Apr & 5 May & Means $^{z}$ \\
\hline \multicolumn{11}{|l|}{ One application } \\
\hline $\mathrm{X}$ & $\ldots$ & $\ldots$ & $\ldots$ & $\ldots$ & $0.6 \mathrm{bcd}$ & $2.6 \mathrm{abcd}$ & $19.4 \mathrm{~b}$ & $21.6 \mathrm{~b}$ & $19.6 \mathrm{bcd}$ & $12.8 \mathrm{~b}$ \\
\hline$\ldots$ & $\mathrm{X}$ & $\ldots$ & $\ldots$ & $\ldots$ & $9.6 \mathrm{a}$ & $0.6 \mathrm{~cd}$ & $16.4 \mathrm{bc}$ & $16.8 \mathrm{~b}$ & $35.0 \mathrm{ab}$ & $15.7 \mathrm{~b}$ \\
\hline$\ldots$ & $\ldots$ & $X$ & $\ldots$ & $\ldots$ & $6.8 \mathrm{a}$ & $8.4 \mathrm{a}$ & $2.0 \mathrm{~d}$ & $7.4 \mathrm{~cd}$ & $20.8 \mathrm{bc}$ & $9.1 \mathrm{bc}$ \\
\hline$\ldots$ & $\ldots$ & $\ldots$ & $\mathrm{X}$ & $\ldots$ & $4.4 \mathrm{ab}$ & $5.9 \mathrm{ab}$ & $35.4 \mathrm{a}$ & $3.2 \mathrm{de}$ & $15.8 \mathrm{~cd}$ & $13.0 \mathrm{~b}$ \\
\hline \multicolumn{11}{|l|}{ Two applications } \\
\hline $\mathrm{X}$ & $\mathrm{X}$ & $\ldots$ & $\ldots$ & $\ldots$ & $0.6 \mathrm{bcd}$ & $0.2 \mathrm{~d}$ & $5.8 \mathrm{~cd}$ & $10.2 \mathrm{c}$ & $12.6 \mathrm{~cd}$ & $5.9 \mathrm{cde}$ \\
\hline $\mathrm{X}$ & $\ldots$ & $X$ & $\ldots$ & $\ldots$ & $3.2 \mathrm{abc}$ & $4.4 \mathrm{abcd}$ & $1.3 \mathrm{de}$ & $9.0 \mathrm{~cd}$ & $18.2 \mathrm{c}$ & $7.2 \mathrm{~cd}$ \\
\hline $\mathrm{X}$ & $\ldots$ & $\ldots$ & $\mathrm{X}$ & $\ldots$ & $0.0 \mathrm{~d}$ & $5.5 \mathrm{abc}$ & $14.9 \mathrm{bc}$ & $0.6 \mathrm{e}$ & $4.8 \mathrm{de}$ & $5.2 \mathrm{def}$ \\
\hline \multicolumn{11}{|l|}{ Three applications } \\
\hline X & $\mathrm{X}$ & $\ldots$ & $\mathrm{X}$ & $\ldots$ & $0.6 \mathrm{bcd}$ & $0.4 \mathrm{~cd}$ & $11.8 \mathrm{bc}$ & $0.0 \mathrm{e}$ & $2.4 \mathrm{e}$ & $3.0 \mathrm{ef}$ \\
\hline $\mathrm{X}$ & $\ldots$ & $\mathrm{X}$ & $\ldots$ & $\mathrm{X}$ & $0.2 \mathrm{~cd}$ & $1.2 \mathrm{bcd}$ & $1.3 \mathrm{de}$ & $5.6 \mathrm{~cd}$ & $0.8 \mathrm{e}$ & $1.8 \mathrm{f}$ \\
\hline Nontreated control & $\ldots$ & $\ldots$ & $\ldots$ & $\ldots$ & $6.2 \mathrm{a}$ & $12.2 \mathrm{a}$ & $48.6 \mathrm{a}$ & $31.4 \mathrm{a}$ & $40.8 \mathrm{a}$ & $27.9 \mathrm{a}$ \\
\hline Means, defoliation date & $\ldots$ & $\ldots$ & $\ldots$ & $\ldots$ & $3.2 \mathrm{e}$ & $4.1 \mathrm{de}$ & $15.7 \mathrm{a}$ & $10.6 \mathrm{~b}$ & $17.1 \mathrm{a}$ & $\ldots$ \\
\hline
\end{tabular}

${ }^{\mathrm{w}}$ Incidence of disease, December 1999 (Dec) and February (Feb), March (Mar) April (Apr), and May 2000. Analysis of variance was performed on arcsine transformed data; nontransformed data are presented. Means down columns (for application) and across the bottom row (means for defoliation date) followed by the same letter do not differ significantly according to Duncan's multiple range test.

x Cupric hydroxide (Kocide DF40), 3 g/liter of water, was applied to run-off using a hand-gun sprayer.

$\mathrm{y}$ Ten adjacent pairs of leaves were removed from each of five healthy 1- or 2-year-old shoots per tree on all trees in the experiment immediately before treatment on each application date. The number of infected wounds on each shoot was counted on 24 July 2000.

${ }^{\mathrm{z}}$ Means for application (season-long total). 
for disease incidence. Disease data for the 1998 season were collected from nontreated control trees in an experiment not reported here but conducted in the same orchard. Five shoots on each of six trees were defoliated, as described above, on 16 December 1997, and 21 January, 27 February, 19 March, 17 April, 6 June, and 30 June 1998. The number of wounds at which galls developed were counted on 26 August 1998.

Inoculum concentration. $P$. savastanoi was grown on King's B medium for 48 to $72 \mathrm{~h}$ at 20 to $22^{\circ} \mathrm{C}$. Inoculum was kept on ice for transport in the field, and the cells were harvested in sterile phosphate buffer and suspensions containing $10^{4}, 10^{6}$, and $10^{8} \mathrm{CFU} / \mathrm{ml}$ were prepared. The $10^{6}$ and $10^{8} \mathrm{CFU} / \mathrm{ml}$ suspensions were adjusted visually. The $10^{4} \mathrm{CFU} / \mathrm{ml}$ suspension was prepared by dilution of a portion of the $10^{6}$ $\mathrm{CFU} / \mathrm{ml}$ suspension. To confirm the concentrations, three 10 -fold dilutions $\left(10^{5}\right.$, $10^{4}$, and $10^{3}$ ) of the $10^{6} \mathrm{CFU} / \mathrm{ml}$ suspension were made, and $0.1 \mathrm{ml}$ of each was spread onto each of three King's B culture plates. The cultures were incubated for 3 to 5 days at 20 to $22^{\circ} \mathrm{C}$. The numbers of colonies were counted on the plates prepared from the $10^{3} \mathrm{CFU} / \mathrm{ml}$ dilution and ranged from 69 to 343 per plate.

Ten adjacent pairs of leaves were removed from seven healthy 1- or 2-year-old shoots on each of 10 trees on 18 December 1997, 28 April 1998, 17 December 1998, and 19 April 1999. On each tree, immediately after defoliation, three shoots were treated with 2.4 (1998) or 3.0 (1999) g of Kocide DF40 per liter of water. After the material dried, the treated shoots, as well as three nontreated, defoliated shoots, were misted with the inocula. The seventh shoot, the nontreated, noninoculated control, was misted with sterile phosphate buffer. The cupric hydroxide, inocula, and phosphate buffer were delivered using handheld pump sprayers. Ten replications of these seven treatments were arranged in a randomized complete block design. The number of infected wounds on each shoot was counted on 26 August 1998 and 18 August 1999.

Statistical design and analysis. The experimental design was a randomized complete block and the treatment design a two-way factorial for the copper timing application and inoculum concentration experiments. The main and subplot factors were application date and defoliation date for the copper application timing experiments and inoculum concentration and inoculation date for the inoculum concentration experiments. An arcsine transformation was performed on the data before analysis of variance. Nontransformed data are presented. Means were separated by Duncan's multiple range test for the copper application timing experiments and by orthogonal contrasts for the inoculum concentration experiments. Correlation co-
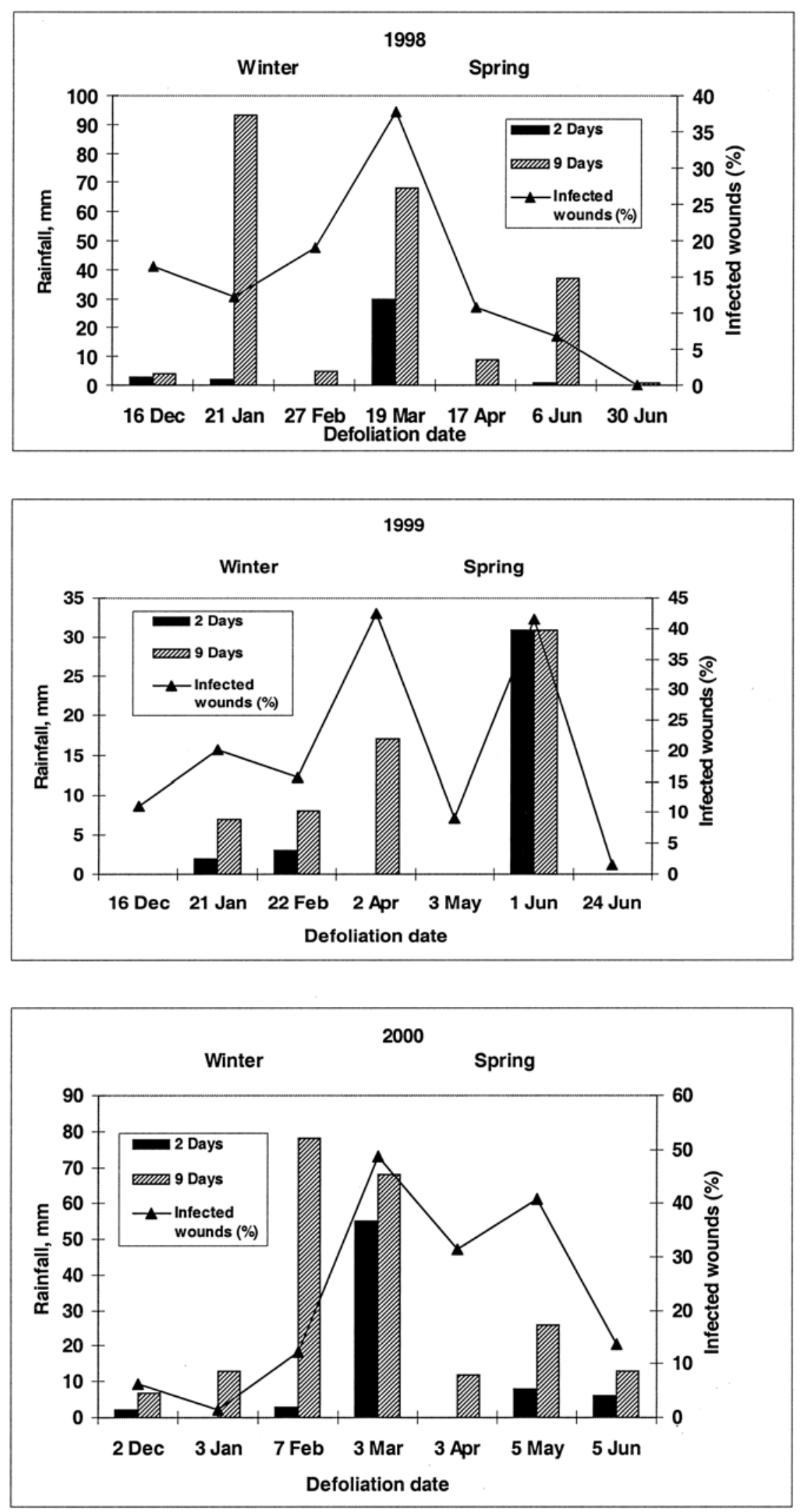

Fig. 1. Effect of rainfall on the incidence of olive knot, caused by Pseudomonas savastanoi, in defoliated 'Manzanillo' olive shoots, Tehama County, CA. Ten adjacent pairs of leaves were removed from each of five shoots on each of six trees in 1998 and five trees in 1999 and 2000 at approximately monthly intervals from December through June each season. The number of galls on each defoliated shoot was counted on 26 August 1998, 18 August 1999, and 24 July 2000. Cumulative amounts of rainfall during the 2- and 9-day periods after defoliation were determined. Data from all 3 years were combined to correlate disease incidence with rainfall. There was no significant correlation between winter (December, January, and February) rainfall and percentage of infected wounds. Spring (March through June) rainfall was positively correlated $(P=0.031$ and 0.023 for 2 and 9 days, respectively). The correlation coefficients for the 2 - and 9 -day periods were 0.617 and 0.642 , respectively. 
efficients for rainfall and disease incidence were calculated using data combined from all 3 years.

\section{RESULTS}

Copper application timing. There were significant differences among copper application timing and defoliation dates in both years (Table 3 ). The greatest percentages of infection in the nontreated controls occurred in April and June 1999 (Table 1) and March and May 2000 (Table 2). Generally, season-long disease control increased with increasing numbers of applications $(P=0.008$ and 0.032 in 1999 and 2000, respectively), and was best and most consistent in trees treated three times. Among the single-application treatments, season-long disease control was slightly better in trees treated in April 1999 and March 2000 than at other times in both years.

Significant interactions were found in both years. In 1999, significant differences among treatments were found on all defoliation dates except 3 May (Table 1). In both years, for each defoliation date, the amount of disease that developed often varied with the date of the most recent application. For instance, in 2000, within the group of treatments that received only one application, disease was least on shoots that were defoliated and treated on the same day: 2 December, 7 February, 3 March, and 3 April (Table 2). This pattern was not as clear in 1999. The 16 December defoliations developed relatively little disease, except for shoots to be treated once in May and the control. Among the single-application treatments, disease incidence for the February defoliation date was less in trees that had been treated once in December or February than in trees not yet treated (April and May treatment dates). However, by April, disease incidence in trees treated only once (in December or February) did not differ from that in nontreated trees (May treatment date and control).

Rainfall and disease incidence. Cumulative amounts of rainfall in winter (December, January, and February) during

Table 4. Analysis of variance for experiments on the effects of inoculum concentration on incidence of olive knot disease on defoliated shoots of 'Manzanillo' olive trees inoculated with Pseudomonas savastanoi, Tehama County, $\mathrm{CA}^{\mathrm{z}}$

\begin{tabular}{|c|c|c|c|c|c|}
\hline \multirow[b]{2}{*}{ Sources of variation } & \multirow[b]{2}{*}{ df } & \multicolumn{2}{|c|}{ 1997-98 } & \multicolumn{2}{|c|}{ 1998-99 } \\
\hline & & MS & $F$ value & MS & $F$ value \\
\hline Replication & 9 & 451.5 & $2.77 *$ & 278.9 & 1.88 \\
\hline Inoculum concentration & 6 & $4,696.7$ & $28.78 * * *$ & $3,963.8$ & $26.7 * * *$ \\
\hline Error & 54 & 163.2 & $\ldots$ & 148.4 & $\ldots$ \\
\hline Inoculation date & 1 & $16,054.9$ & $74.93 * * *$ & $2,496.6$ & $20.60 * * *$ \\
\hline Inoculum $\times$ inoculation date & 6 & 332.6 & 1.55 & 685.2 & $5.65^{* *}$ \\
\hline Error & 63 & 214.2 & $\ldots$ & 121.1 & $\ldots$ \\
\hline
\end{tabular}

$\mathrm{z}$ Analysis of variance was performed on arcsine transformed data. Values followed by $*, * *$, or $* * *$ are significantly different at $P<0.01,0.001$, and 0.0001 , respectively. the first 2 and 9 days after defoliation were not significantly correlated to disease incidence (Fig. 1). By contrast, rainfall and disease incidence in spring (March through June) were positively correlated $(P=0.031$ and 0.023 for 2 and 9 days, respectively). The correlation coefficients for the 2- and 9-day periods were 0.617 and 0.642 , respectively. Relatively low levels of olive knot developed on shoots defoliated during winter, regardless of how much rain fell, whereas disease incidence generally was higher in spring, and increases in rain were accompanied by increases in olive knot

Inoculum concentration. There were significant differences among inoculum concentrations and between December and April inoculation dates in both years (Table 4). Disease incidence generally was lower from December than from April inoculations, from noninoculated than from inoculated treatments, and where cupric hydroxide was applied (Table 5).

The percentage of infected wounds increased with increasing inoculum concentration. A significant interaction occurred between inoculum concentration and inoculation date in 1998-99. In December inoculations, shoots treated with cupric hydroxide developed slightly more olive knot than inoculated nontreated shoots; whereas, in April, olive knot incidence in treated shoots was less than half that in inoculated, nontreated shoots.

Cupric hydroxide reduced disease in shoots inoculated with $10^{8} \mathrm{CFU} / \mathrm{ml}$ in April 1999 but not in April 1998. The failure of cupric hydroxide to lessen disease in the high-inoculum treatment in April 1998 may be attributed to the combination of bactericide rate and weather fa-

Table 5. Effects of inoculum concentration on incidence of olive knot disease on defoliated shoots of 'Manzanillo' olive trees inoculated with Pseudomonas savastanoi, Tehama County, CA

\begin{tabular}{|c|c|c|c|c|c|c|}
\hline \multirow[b]{3}{*}{ Treatment ${ }^{y}$} & \multicolumn{6}{|c|}{ Infected wounds $(\%)^{x}$} \\
\hline & \multicolumn{3}{|c|}{ 1997-98 } & \multicolumn{3}{|c|}{ 1998-99 } \\
\hline & 18 December & 28 April & Means & 17 December & 19 April & Means \\
\hline \multicolumn{7}{|l|}{ Inoculated } \\
\hline \multicolumn{7}{|l|}{ Treated with cupric hydroxide } \\
\hline $10^{8} \mathrm{CFU} / \mathrm{ml}$ & 32.5 & 85.5 & 59.0 & 55.5 & 47.0 & 51.2 \\
\hline $10^{6} \mathrm{CFU} / \mathrm{ml}$ & 22.0 & 49.0 & 35.5 & 28.0 & 22.0 & 25.0 \\
\hline $10^{4} \mathrm{CFU} / \mathrm{ml}$ & 4.0 & 24.0 & 14.0 & 11.0 & 15.0 & 13.0 \\
\hline \multicolumn{7}{|l|}{ Nontreated with cupric hydroxide } \\
\hline $10^{8} \mathrm{CFU} / \mathrm{ml}$ & 59.5 & 87.5 & 73.5 & 41.5 & 80.0 & 60.7 \\
\hline $10^{6} \mathrm{CFU} / \mathrm{ml}$ & 27.0 & 61.0 & 44.0 & 18.0 & 45.5 & 31.7 \\
\hline $10^{4} \mathrm{CFU} / \mathrm{ml}$ & 27.5 & 42.5 & 35.0 & 6.5 & 17.5 & 12.0 \\
\hline Nontreated, noninoculated control & 10.5 & 46.0 & 28.2 & 7.5 & 21.0 & 14.2 \\
\hline Means for inoculation date & 26.1 & 56.5 & $\ldots$ & 24.00 & 35.4 & $\ldots$ \\
\hline \multicolumn{7}{|l|}{ Orthogonal contrasts ${ }^{\mathrm{z}}$} \\
\hline Inoculated versus noninoculated & ** & NS & ** & $* * *$ & ** & $* * *$ \\
\hline With versus without cupric hydroxide & $* * *$ & $*$ & $* * *$ & ** & $* * *$ & NS \\
\hline Linear & $* * *$ & **** & **** & $* * *$ & **** & $* * *$ \\
\hline Quadratic & NS & NS & NS & NS & NS & NS \\
\hline
\end{tabular}

${ }^{x}$ Ten adjacent pairs of leaves were removed from one healthy 1- or 2-year-old shoot for each treatment on each of 10 trees on each date. The number of infected wounds on each shoot was counted on 26 August 1998 and 18 August 1999.

y Defoliated shoots were treated immediately with a water suspension of 2.4 or $3.0 \mathrm{~g}$ cupric hydroxide (Kocide DF40) per liter in December and April of 1997-98 and 1998-99, respectively. After the material dried, treated and nontreated shoots were inoculated with suspensions of P. savastanoi in sterile phosphate buffer using a handheld pump sprayer. Means $=$ means for treatment.

$\mathrm{z}$ Analysis was performed on arcsine transformed data. Values indicated by $*$, $* *$, or $* * *$ are significantly different at $P=<0.01,<0.001$, and $<0.0001$, respectively; NS $=$ not significant, $P=>0.05$. 
vorable to disease. The rate of Kocide used in 1997-98 was lower than that used in 1998-99, and $21 \mathrm{~mm}$ of rain fell during the 3- to 5-day period following inoculation. No rain fell during the 9 days after any other inoculation date.

The presence of the pathogen in the orchard may have compromised some of our results. In three instances, somewhat more disease developed in the nontreated, noninoculated control shoots than in nontreated shoots inoculated with $10^{4} \mathrm{CFU} / \mathrm{ml}$, but the differences were not significant. At these low concentrations, sufficient natural inoculum apparently was present to obscure the effects of inoculation. Nonetheless, disease incidence increased with increasing concentrations of inoculum in treated and nontreated shoots in both years.

\section{DISCUSSION}

Our studies employed artificial wounds on shoots instead of naturally occurring leaf scars. Infection and protection of these artificial wounds may have differed from that of natural leaf scars. Although the artificial wounds were more abrupt and severe than those caused by natural defoliation, they shared some characteristics with natural leaf scars. Olive leaves do not produce a protective layer of cells in the abscission zone (5). Instead, the release of the petiole is a mechanical event that exposes open vascular elements (3). Our wounds, also mechanical events, probably exposed a larger region of vascular tissues and may have remained susceptible longer than the 9 days during which true leaf scars are vulnerable.

Previous research associated disease incidence with rainfall and the presence of wounds, principally leaf scars (8). A severe outbreak of olive knot in spring 1933 was attributed to a freeze the previous December that caused excessive defoliation during winter. By contrast, the comparatively little disease found in 1934 was credited to a scarcity of susceptible leaf scars present during winter rains. In addition to these observations, potted trees, which had been wounded by puncturing or cutting the bark, were placed in diseased orchards for periods of several weeks at various times of the year. The greatest amount of olive knot developed in trees that had been exposed to long winter rains. In our experi- ments, disease incidence consistently was lower in winter than spring and was less affected by winter than spring rainfall. The length of time that bark wounds and simulated leaf scars remain susceptible at different times of the year, though unknown, may differ. Also, we correlated disease incidence to the cumulative rainfall only during the putative susceptibility period ( 2 and 9 days after wounding) for leaf scars.

Past research on spray application timing concentrated on multiple applications spanning fall, winter, and early spring $(4,8)$. Treatments in mid- and late spring were not included. Our work established the effectiveness of mid- and late-spring applications and demonstrated the connection between spring rain and disease incidence. Results of the copper application timing tests were largely consistent for both years. The lack of rain following the defoliations in December 1998 and May 1999 may have contributed to the relatively low disease incidences found then. Although there were some variations between years in the results for individual defoliation dates, the patterns of seasonlong control were similar for both years. Phytotoxicity to fruit, flowers, or leaves was not observed in any of our tests.

We recognize the difficulties inherent in conducting inoculation studies in an orchard contaminated with the pathogen. Our experiments were not intended to develop relationships between absolute amounts of inoculum and disease or to establish data useful for the development of predictive models. Rather, the experiments were intended to show that increasing amounts of inoculum would result in greater disease incidence. This was accomplished in every instance, regardless of background infection levels, and treatment with cupric hydroxide did not nullify the effects of inoculum concentration on disease incidence.

Much of our understanding of olive knot disease is based upon observations. In addition to natural leaf fall, frost injury and olive leaf spot disease can cause excessive defoliation in late winter and spring. Orchards with either condition that also harbor the olive knot pathogen frequently develop severe outbreaks of olive knot. The assumption is that the increased number of leaf scars and wounds leads to more infection by $P$. savastanoi, but the relationships between frost or olive leaf spot and olive knot have not been studied. Definitive work on how climatic factors and inoculum potential affect olive knot epidemics also is lacking.

The current control guidelines for California growers recommend that two copper spray treatments should be applied from postharvest though early spring (2). Precise timing is not detailed except that sprays should be timed to protect as many fresh leaf scars as possible. Although olive trees drop leaves all year long, in normal years, most leaves fall in spring, from March through June. This should render olive trees in California at greatest risk of olive knot infection in spring, when most leaves fall and rains occur. The common grower practice has been to apply a copper bactericide once after harvest. Our work establishes the importance of additional sprays in spring for control of olive knot disease, and aids growers in making management decisions regarding the timing and number of treatments.

\section{LITERATURE CITED}

1. Ercolani, G. L. 1978. Pseudomonas savastanoi and other bacteria colonizing the surface of olive leaves in the field. J. Gen. Microbiol. 109:245-257.

2. Flint, M. L. ed. 2002. University of California Pest Management Guidelines. Agricultural and Natural Resources Publication 3452. Oakland, CA.

3. Hewitt, W. B. 1938. Leaf-scar infection in relation to the olive knot disease. Hilgardia 12:(1)41-65.

4. Krueger, W. H., Teviotdale, B. L., and Schroth, M. N. 1999. Improvements in the control of olive knot disease. Acta Hortic. 474:567-571.

5. Martin, G. C., Klonsky, K., and Ferguson, L. 1994. The olive harvest. Pages 117-128 in: Olive Production Manual. L. Ferguson, G. S. Sibbett, and G. C. Martin, eds. Publ. 3353, Division of Agriculture and Natural Resources, University of California, Oakland.

6. Ogawa, J. M., and English, H. 1991. Olive knot. Pages 341-344 in: Diseases of Temperate Zone Tree Fruit and Nut Crops, Publ. 3345, Division of Agriculture and Natural Resources, University of California, Oakland.

7. Schroth, M. N., Osgood, J. W., and Miller, T. D. 1973. Quantitative assessment of the effect of the olive knot disease on olive yield and quality. Phytopathology 63:1064-1065.

8. Wilson, E. E. 1935. The olive knot disease: Its inception, development and control. Hilgardia 9:(4)233-264.

9. Wilson, E. E., and Magie, A. R. 1964. Systemic invasion of the host plant by the tumor inducing bacterium, Pseudomonas savastanoi. Phytopathology 54:567-579. 